http://dx.doi.org/10.12775/szhf.2019.005

\author{
HonORATA JaKuszKo \\ Uniwersytet Marii Curie-SkŁodowskiej w Lublinie, Polska \\ ORCID: 0000-0001-8334-1318 \\ E-MAIL: HJAKUSZKO@BACON.UMCS.LUBLIN.PL
}

\title{
Kondycja ludzka według Pierre’a Bayle’a
}

Pierre Bayle, inicjator oświecenia francuskiego, znany głównie jako autor słynnego Dictionnaire historique et critique (1696-1697), wydał anonimowo w 1682 roku w Rotterdamie Pensées diverses sur la comète, przełożone przez Johanna Christopha Gottscheda w 1741 roku pt. Verschiedene Gedanken über einen Kometen ${ }^{1}$. Było to pismo polemiczne, zawierające listy adresowane do doktora Sorbony, perypatetyka i katolika. Mimo różnicy poglądów Bayle (sympatyk kartezjanizmu i hugenot) wyrażał nadzieję na zrozumienie ze strony swojego adresata. Jak pisał, „zapewne znajdzie Pan w tym zakończeniu łatwy środek pojednania wglądu filozofii ze światłem sumienia”2. Wprawdzie jego stanowisko skłaniało się do sceptycyzmu, jednak należy zgodzić się z tezami Izydory Dąmbskiej, że nie był to sceptycyzm radykalny, tylko umiarkowany, nie był to też sceptycyzm całkowity, tylko częściowy, ponieważ nie dotyczył prawd wiary, które opierają się na pozaracjonalnej pewności

\footnotetext{
${ }^{1} \mathrm{~W}$ niniejszym artykule opieram się wyłącznie na wspomnianym przekładzie. Zob. Pierre Bayle, Verschiedene einem Doktor der Sorbonne mitgeteilte Gedanken über den Kometen, der im Monat Dezember 1680 erschienen ist, przeł. Johann Christoph Gottsched (Leipzig: Verlag Philipp Reclam, 1975). Wszelkie cytaty z tekstu źródłowego podaję we własnym przekładzie.

2 Tamże, 539-540.
} 
Objawienia, wreszcie nie był to sceptycyzm normatywny, tylko teoretyczny, odnoszony wyłącznie do wiedzy osiąganej na drodze naturalnych zdolności poznawczych człowieka ${ }^{3}$. Nie będzie przesadą teza, że Bayle stosował sceptycyzm metodyczny po to, by krzewić zdrową i rzetelną filozofię. Sceptycyzm nie jest ostatnim słowem filozofa, który uważał, że warto realizować misję oczyszczania umysłów z przesądów (Vorurteile), upowszechniania zdrowych reguł metodologicznych, unikania pochopnych uogólnień oraz wyważania różnych racji danego poglądu.

Zawartość dziełka jest bogatsza, niż można by sądzić na podstawie tytułu. Nie tylko bowiem komety są przedmiotem zainteresowania Bayle’a, podejmującego próbę wyjaśnienia zjawiska, które w grudniu 1680 roku wzbudziło trwogę mieszkańców Francji, przekonanych, że kometa (zjawisko rzadko spotykane w przyrodzie) zapowiada wszelkie przyszłe nieszczęścia. Bayle uważał, że jest to jeden z powszechnych przesądów, które zaciemniają światło rozumu (Licht der Vernunft) i światło sumienia (Licht des Gewissens) ${ }^{4}$. Z tego powodu postanowił napisać wcześniej już planowaną pracę wymierzoną przeciw przesądom, jak potwierdza to korespondencja Bayle'a z przyjacielem Vincentem Minutolim z 1679 roku$^{5}$. Przez przesąd rozumiał Bayle pochopnie podjęty sąd bez zbadania stojących za nim racji rozumu oraz bez podjęcia próby weryfikacji owego sądu w szeroko rozumianym doświadczeniu, włączającym różne świadectwa pisemne gromadzone przez całe stulecia ${ }^{6}$. Zdaniem Bayle’a „Można mówić, co się chce, nasze siły nigdy jednak nie działają,

${ }^{3}$ Izydora Dąmbska, Sceptycyzm francuski XVI i XVII wieku (Łódź: Państwowe Wydawnictwo Naukowe, 1958), 7-11, 14-15, 66-71. Por. Richard Henry Popkin, The History of Scepticism from Savonarola to Bayle (Oxford: Oxford University Press, 2003), 231. Renata Ziemińska, Historia sceptycyzmu. W poszukiwaniu spójności (Toruń: Wydawnictwo Naukowe Uniwersytetu Mikołaja Kopernika, 2013), 233-241. Adam Grzeliński, „Wprowadzenie”, w: Pierre Bayle, Słownik historyczny i krytyczny. Wybór, przeł. Kinga Kaśkiewicz, Adam Grzeliński i in. (Toruń: Wydawnictwo Naukowe Uniwersytetu Mikołaja Kopernika, 2014), 25-26.

${ }^{4}$ Bayle, Verschiedene, 476, 289, 539. Tematyka przesądu (fr. prejudice, niem. Vorurteil, ang. superstition) bardzo często była podejmowana przez przedstawicieli oświecenia francuskiego, niemieckiego i brytyjskiego. W literaturze niemieckojęzycznej systematycznie tę kwestię przedstawia Werner Schneiders, Aufklärung und Vorurteilskritik. Studien zur Geschichte der Vorurteilstheorie (Stuttgart: Frommann-Holzboog, 1983).

${ }^{5}$ Rolf Geißler, „Einleitung”, w: Pierre Bayle, Verschiedene, 11.

${ }^{6}$ Bayle, Verschiedene, 43. 
jeśli przedmioty nie stoją z nimi we właściwej relacji”" Można słusznie wnioskować przez analogię, że skoro wzrok ludzki nie widzi przedmiotów zbyt małych, zbyt oddalonych i nieoświetlonych, podobnie światło rozumu zostaje zaciemnione przez niedorzeczne przesądy, które udaremniają właściwe relacje z przedmiotami badanymi.

Uwagę czytelnika zwraca ogromna, drobiazgowa wręcz erudycja Bayle’a, który odwoływał się do pism Starego i Nowego Testamentu, filozofów starożytnych (Cycerona, Seneki, Diogenesa Laertiosa, Tacyta, Herodota i Liwiusza), myślicieli patrystycznych (Klemensa Aleksandryjskiego, Orygenesa, Laktancjusza, Tertuliana i Augustyna) oraz filozofów nowożytnych (Montaigne'a, La Mothe le Vayera, Descartesa, Gassendiego, Pascala, Malebranche’a i Arnaulda). Bayle uważał, że zwłaszcza filozofia we Francji pracuje nad eliminacją przesądów i wzmocnieniem rozumu, co można porównać do pracy Herkulesa, który oczyszczał stajnię Augiasza ${ }^{8}$.

Bayle posługiwał się językiem jasnym i zrozumiałym, ponieważ chciał dotrzeć nie tylko do profesjonalnych uczonych, ale także do szerokiej publiczności, co stanowi znamienny rys piśmiennictwa oświecenia. Jego zdaniem powinno być dozwolone, by badać i upowszechniać prawdę wszystkich rzeczy, jeśli się postępuje w sposób rzetelny i ostrożny. Odrzucał pogląd, reprezentowany przez urzędników zarówno państwa, jak i Kościoła, że wielu prawd nie potrzebuje znać plebs, a nawet lepiej, gdyby wierzył w rzeczy nieprawdziwe ze względu na użyteczność tej wiary9.

Sposób prowadzenia wywodu przez Bayle’a może stwarzać trudności, a nawet powodować zniecierpliwienie czytelnika, czego świadom był sam autor. „Tu zatrzymam się i dziwię się samemu sobie, jeśli zwracam wzrok na nadmierną rozwlekłość tego pisma, a jeszcze bardziej, jeśli pomyślę, jakie osobliwe pomieszanie panuje w nim. O czym tu nie mówiłem?" ${ }^{10}$ Bayle pisał, że zgromadził różne myśli przeczytane w książkach (historiach starożytnych, historiach zakonów, dziennikach podróży), zasłyszane w opowiadaniach członków danej społeczności, a także przemyślane przez niego samego. Zwracając się do adresata pisma, stwierdzał, że „będzie Pan mógł łatwo za-

\footnotetext{
7 Tamże, 401.

${ }^{8}$ Tamże, 72-73. Niewątpliwie Bayle miał na myśli zasługi kartezjanizmu.

9 Tamże, 202.

10 Tamże, 533.
} 
uważyć w tym dziele nieuporządkowaną istotę, która znajduje się w mieście. Ponieważ w mieście buduje się w różnym czasie i ulepsza to $\mathrm{w}$ tym, to $\mathrm{w}$ innym miejscu, widzi się więc często, że mały dom stoi obok dużego, stary obok nowego. Tak jest $\mathrm{z}$ moimi różnymi myślami. Często powracałem, ażeby to tu, to tam móc wprowadzić uzupełnienia" ${ }^{11}$. Wynika stąd, że Bayle nie dbał o porządek hierarchiczny przedstawianych poglądów ani nie miał ambicji tworzenia systemu, w którym z przyjętych a priori zasad ogólnych można wyprowadzać wszelkie szczegółowe wnioski. Odnosi się wrażenie, że różne wątki myślowe obecne w dziele Bayle’a mają równorzędne znaczenie oraz realizują przede wszystkim główny cel, którym jest odkrywanie błędów w ludzkiej wiedzy o świecie ${ }^{12}$.

Bayle'a interesował nie tylko aspekt genetyczny ludzkiej wiedzy, m.in. to, jak powstają przesądy, jak są upowszechniane i podtrzymywane oraz jakie pełnią funkcje społeczne, ale także (i przede wszystkim) aspekt metodologiczny ludzkiej wiedzy: jakie są wartościowe narzędzia poznania, gwarantujące wiedzę przynajmniej bardziej prawdopodobną niż mniej prawdopodobną, strzegące przed wiedzą jawnie fałszywą, jakie kryteria prawdy są nie do zaakceptowania, a jakie warto przyjmować.

Odnosząc się do aspektu genetycznego wiedzy, można zauważyć, że - zdaniem Bayle’a - przesądy mają źródło w naturalnej skłonności człowieka do dawania wiary świadectwom i świadkom (poetom, historykom, teologom, filozofom) zajmującym poczesne miejsce $\mathrm{w}$ tradycji, która niesłusznie jest traktowana jako podstawa ludzkich mniemań. Długowieczność i trwałość przesądów wiąże się z łatwowiernością i lenistwem umysłowym jednostek ludzkich, które nie pytają o radę swego rozumu, jeśli uznają za prawdziwe to, co usłyszały od innych, nie podejmując krytycznego badania odziedziczonych świadectw historycznych po to, by móc ocenić ich wiarygodność, stopień prawdopodobieństwa lub pewności ${ }^{13}$. Ponadto $\mathrm{w}$ podtrzymywaniu przesądów biorą udział ludzkie namiętności, będące właściwym motorem

${ }^{11}$ Tamże, 533-534.

12 Zwraca na to uwagę Ernst Cassirer, Die Philosophie der Aufklärung (Tübingen: J. C. B. Mohr (Paul Siebeck), 1973), 269-279. We wszystkich pracach Baylea, nie tylko w Dictionnaire historique et critique (1696-1697), ale także w analizowanej publikacji Pensées diverses sur la comète można śledzić tę metodę.

${ }^{13}$ Bayle, Verschiedene, 44, 115. 
ludzkich działań. Na przykład strach przed przyszłością i nigdy nienasycona żądza doświadczania tego, co ma zdarzyć się w przyszłości, skłania do błędnych wnioskowań na podstawie rzekomo cudownych znaków na niebie, takich jak komety ${ }^{14}$. Słabość tę z rozmysłem wykorzystują astrologowie, którzy każą sobie płacić za stawiane horoskopy, mniemając niesłusznie, że są w posiadaniu Księgi Nieba, traktującej o rzeczach przeszłych, teraźniejszych i przyszłych. Również reprezentanci władzy świeckiej oraz religijnej są zainteresowani podtrzymywaniem przesądów, które łatwiej pozwalają podporządkować sobie bezmyślne pospólstwo.

Godne podkreślenia jest to, że Bayle bronił prawa każdej jednostki ludzkiej do własnego sądu. Jego zdaniem, ,jeśli przy wielu powszechnych błędach każdy ma prawo, by wymagać od innych posłuchu dla jego mniemania, również ci, którzy go słuchają, zachowują prawo, by przynajmniej bronić się (nie przez argument starożytności czy przesąd większej liczby zwolenników), lecz przez gruntowne badanie prawdy"15.

Jak Bayle rozumiał gruntowne badanie prawdy, można odczytać z reguł metodologicznych rozproszonych w całości jego dzieła. Tytułem przykładu warto przywołać zalecenia takie jak":

- Należy badać rzecz skrupulatnie, oglądając ją z wielu stron ${ }^{16}$.

- Nie wolno ulegać nawykowi sądzenia o rzeczach na podstawie pierwszego wrażenia, czyli tego, co dyktują zmysły i namiętności ${ }^{17}$.

- Nie należy kierować się liczbą zwolenników danego poglądu, lecz badać jego racje ${ }^{18}$.

- Nie należy uznawać argumentu dawności czy starożytności poglądu za wystarczające kryterium prawdy, a raczej krytycznie badać świadectwa historyczne, tropiąc w nich luki, niejasności i sprzeczności ${ }^{19}$.

\footnotetext{
14 Tamże, 169.

${ }^{15}$ Tamże, 73-74. Warto w tym miejscu dodać, że Bayle wyłącza z krytycznego badania objawione prawdy wiary (np. Trójcę Świętą, Wcielenie Syna Bożego), ograniczając się wyłącznie do przedmiotów poznawalnych na drodze naturalnych zdolności człowieka.

16 Tamże, 44, 73, 329.

17 Tamże, 76.

${ }^{18}$ Tamże, 117. Consensus omnium nie jest kryterium prawdy, dlatego „nie należy liczyć głosów, lecz je wyważać".

19 Tamże, 185, 225.
} 
- W badaniu warto uwzględniać pierwsze zasady rozumu, odrzucając tym samym to, co jest z nimi sprzeczne, niedorzeczne czy wręcz śmieszne ${ }^{20}$.

- Należy uwzględniać pomoc doświadczenia (Erfahrung), które potwierdza lub obala pewne zasłyszane poglądy, a także formułowane przypuszczenia (Mutmaßungen) na dany temat ${ }^{21}$.

- Z dużym prawdopodobieństwem można przyjąć, że poglądy uznane za pożyteczne, które wkradły się do umysłów pod wpływem określonych namiętności, są fałszywe, czyli niepotwierdzone w doświadczeniu, np. traktowanie religii jako niezbędnej podpory więzi społecznej oraz zaprzeczanie, jakoby mogło istnieć państwo ateistów ${ }^{22}$.

Przykładem zastosowania wspomnianych reguł metodologicznych jest powracający wielokrotnie wątek dotyczący przesądu, że komety są przyczynami przyszłych nieszczęść ludzkich lub przynajmniej ich oznakami. Bayle podawał zarówno racje przyrodnicze, jak i argumenty teologiczne wymierzone przeciwko owemu przesądowi. Patrząc z perspektywy przyrodoznawstwa, można stwierdzić, że komety nie mogą być przyczynami sprawczymi ludzkich nieszczęść (wypadki dżumy, wojny, zgony władców), raczej należą one do naturalnego i koniecznego porządku rzeczy, co więcej - można przewidzieć czas i miejsce ich pojawiania się; nie mogą być również oznakami nieszczęść, ponieważ zdarzają się we wszystkich czasach i krajach, niekiedy częściej niż cztery razy w roku. Patrząc z perspektywy teologii, należy uznać, że Bóg nie czyni rzeczy niekoniecznych (czyli cudów) sprzecznych z Jego świętością. Zgodnie bowiem z zasadą nauczaną w szkołach teologów i filozofów, iż nie należy mnożyć bytów (w tym cudów) bez potrzeby, nie można szukać ucieczki w cuda, jeśli rzeczy dają się wyjaśnić w sposób naturalny. Niezgodne z rozumem byłoby także założenie, że Bóg zsyłałby komety w czasach pogańskich w celu zapobieżenia ateizmowi, a tym samym wzmocnienia bałwochwalstwa rzekomo lepszego od całkowitej niewiary. Ponadto - jak argumentował Bayle - Bóg nie jest zwodzicielem, stąd nie może kierować się

\footnotetext{
${ }^{20} \mathrm{~Np}$. teza post hoc ergo propter hoc (tamże, 75). Także vox populi vox Dei (tamże, 117).

${ }^{21}$ Tamże, 115-116. Bayle pisał, że jeden świadek, który widział rzecz (Sache), jest ważniejszy od 10 ludzi, którzy o niej tylko słyszeli. Pogląd jednego zdolnego człowieka, który przemyślał daną rzecz, niepodlegającą już wątpieniu, ma większą wagę niż 100000 zwykłych umysłów, którzy ślepo opierają się jedynie na wiarygodności innych.

${ }^{22}$ Tamże, 74.
} 
zamiarem, by wszyscy ludzie w świecie sądzili, że kometa jest oznaką nieszczęścia ${ }^{23}$.

W innym miejscu swego pisma polemicznego Bayle przeprowadził następującą argumentację: jeśli komety miałyby zapowiadać przyszłe nieszczęścia, musiałyby być albo przyczynami sprawczymi owych nieszczęść, albo ich znakami naturalnymi bądź ustanowionymi przez Boga.

Teza pierwsza - zdaniem Bayle’a - może być nazwana kacerstwem z religijnego punktu widzenia, ponieważ przypisuje kometom sprawczość, która jest przywilejem wyłącznie Boga. Ponadto zawiera jawną niedorzeczność $\mathrm{z}$ tego względu, że nie można wykazać a priori, iż komety mają siłę sprawczą. Nie można także wykazać a posteriori, że nieszczęścia, następujące po zjawieniu się komety, byłyby jej skutkiem, ponieważ doświadczenie rejestruje jedynie zwykłe następstwo faktów, a nie ich wynikanie z siebie. Nie ma żadnych wątpliwości co do tego, by uznać za fałszywe założenie, że we wszystkich częściach świata, w których były widziane komety, pojawiały się same nieszczęścia. Lektura źródeł historycznych obala z łatwością tego rodzaju przekonanie, ponieważ upadek danego państwa zazwyczaj jest triumfem innego państwa.

Teza druga, według której komety miałyby być znakami naturalnymi, nie daje się utrzymać, ponieważ - jak zauważał Bayle - musiałoby to znaczyć, że albo komety byłyby przyczynami sprawczymi, albo musiałby istnieć związek konieczny między nimi a rodzajami nieszczęść następującymi w czasie późniejszym, co już zostało przezeń odparte. Gdyby komety natomiast miały być znakami odróżnionymi od naturalnych (czyli ustanowionymi), Bóg musiałby w braku wyraźnego objawienia wyposażyć je w szczególne zewnętrzne wyróżniki, które pozwalałaby sądzić, że mają one status przepowiedni. Jednak Bóg tego nie uczynił, jak w przypadku tęczy jako znaku przymierza między Nim a ludem wybranym, o czym pisze Księga Mojżesza. Nie można przypisywać Bogu zamiaru zaszczepienia w ludziach łatwowierności. Trudno również zaakceptować tezę, że komety są znakami wytworzonymi przez cud w tym celu, by wszystkich ludzi przestrzec przed gniewem Boskim. Prowadziłoby to bowiem do wzmożenia praktyk bałwochwalczych (np. ofiar ze zwierząt, a nawet ludzi), co byłoby obrazą Boga, a nie realizacją Jego planów.

\footnotetext{
${ }^{23}$ Tamże, 126.
} 
Bayle wnioskował zatem, że komety - wbrew utrwalonemu przesądowi nie są ani przyczynami, ani znakami $\mathrm{w}$ jakimkolwiek rozumieniu tego słowa, raczej są ciałami tak starymi jak Ziemia, określonymi przez prawa ruchu, według których Bóg rządzi machiną świata. Zgodnie z owymi prawami komety od czasu do czasu przybliżają się do nas, stają się widoczne oraz przesyłają nam rozproszone światło Słońca, co postrzegamy jako ogon komety $^{24}$.

W innym miejscu swego pisma polemicznego Bayle pisał:

jest jasne, że albo komety niczego nie zapowiadają, albo że nie zostały one spowodowane przez siłe przyczyn naturalnych, tylko przez Boga samego. Można powiedzieć, że albo Bóg dał pewnej materii postać komety, nie zważając na własności ani na aktywność ciał otaczających (tak jest według Pana, ponieważ Pan jest perypatetykiem), albo nadał tej samej materii kształt cząsteczek, położenie, gęstość i ruch, który musi mieć kometa, lecz nie posłużył się przy tym ruchem, który już był wszczepiony w ciała sąsiednie, i nie kierował się również według praw przekazywania ruchu, które sam ustanowił (tak jest według zasad Pana Descartesa). Jeśli Bóg - jak mówię - może sprawiać, co chce na jeden $\mathrm{z}$ obu sposobów, to właściwie wychodzi na jaw za każdym razem tak zwane dzieło cudowne ${ }^{25}$.

Przyjęcie takiego założenia w kwestii komet traktowanych jako cuda wcale nie uchyla powracających na nowo trudności. Można zasadnie wątpić, czy byłoby to zgodne z mądrością Boga, gdyby Bóg zsyłał dżumę, wojny i inne rodzaje zła jako następujące po kometach. Oznaczałoby to także obrazę Boga, gdyby odebrać mu wolność wyboru czasu, w którym są zsyłane kary. Rozsądniej jest przyjąć, że zjawiska na niebie nie mają żadnego związku

\footnotetext{
${ }^{24}$ Tamże, 535-539. Rozumowanie Bayle’a, wykazujące, że nie możemy ani a priori, ani a posteriori udowodnić sprawczości zdarzenia wcześniejszego w stosunku do późniejszego, można porównać z Hume’owską krytyką związku przyczynowego. David Hume znał prace Bayle’a, o czym przekonuje jego korespondencja z Michaelem Ramsayem, zob. Adam Grzeliński, „Wprowadzenie”, w: Pierre Bayle, Słownik historyczny i krytyczny. Wybór, przeł. Adam Grzeliński, Kinga Kaśkiewicz i in. (Toruń: Wydawnictwo Naukowe Uniwersytetu Mikołaja Kopernika), 9.

${ }^{25}$ Bayle, Verschiedene, 448. W innym miejscu pisma polemicznego Bayle referował pięć znanych mu poglądów o kometach, stwierdzając, że żaden z nich nie zakłada związku naturalnego między kometami a przyszłymi nieszczęściami ludzkimi (tamże, 431).
} 
z przyrostem zła, będącego przecież dziełem ludzkiej wolności, a nie praw mechaniki obowiązujących jedynie w świecie ciał. Ponadto gdyby komety były cudami, należałyby do klasy takich cudów, których Bóg nigdy nie sprawiałby w krajach mieszkańców niewierzących, niezdolnych do odczytania takiego $\mathrm{znaku}^{26}$. Jak argumentował Bayle, oglądanie zdarzeń szczegółowych takich jak komety nie przyczynia się w żadnej mierze do lepszego poznania natury Boga, którego mądrość przejawia się we wspaniałej symetrii, porządku i pięknie całego widzialnego świata. Słusznie mawiali filozofowie nowożytni, że Bóg objawia się nie tylko przez swoje Słowo w Biblii, ale także w Księdze Przyrody, której głębi nigdy nie jest w stanie uchwycić ludzki rozum $^{27}$. Po wykazaniu niedorzeczności założenia, że komety miałyby być zwiastunami sądu Boga lub cudami (zdarzeniami nadnaturalnymi), co nie daje się potwierdzić ani przez konieczne racje rozumu, ani przez nieomylne świadectwo doświadczenia, Bayle skłaniał się do tezy, że komety są dziełami natury. Przywoływał zasadę ekonomii myślenia, zgodnie z którą w wyjaśnieniach nie należy uciekać się do cudu, jeśli można wskazać przyczyny naturalne.

Odnosił się także do zarzutu, że powołując się na naturę, uszczuplamy władztwo Boga nad światem. Uważał bowiem za fałszywą zasadę, że wszystko to, co przyznaje się naturze, zostaje odebrane obszarowi Boga. Wyjaśniał czytelnikom, że

w zdrowej filozofii (gesunde Weltweisheit) natura nie jest niczym innym jak skutkiem Boga samego, który działa albo według pewnych praw, które ustanowił z najwyższą wolnością, albo przez użycie stworzeń, które uczynił i które zachowuje. W ten sposób dzieła natury są tak samo skutkiem mocy Boga jak cuda i wymagają nie mniej wszechmocy jak dzieła cudowne, ponieważ równie trudno jest wytworzyć człowieka przez naturalne płodzenie, jak wskrzesić zmarłego. Cała różnica między cudami i dziełami natury polega na tym, że te ostatnie są bardziej przydatne, ponieważ pozwalają nam poznać, że Bóg jest wolną przyczyną wszystkiego tego, co sprawiają ciała, uwalniając nas od błędu, w który moglibyśmy popaść: stąd wnioskuje się również naturalnie: To, co zdarzałoby się przez cud, byłoby skutkiem albo szczególnej dobroci

\footnotetext{
26 Tamże, 451.

27 Tamże, 456.
} 
albo sprawiedliwości Boga. Stąd nie wynika jeszcze, że należy brać za złe to, że filozofowie tak długo wiążą się z naturą, jak tylko mogą ${ }^{28}$.

Powołując się na światło rozumu, które umożliwia poznawanie Boga w Jego stworzeniach, Bayle przyjmował tezę o ogólnej Opatrzności (allgemeine Vorsorge), która działa zgodnie z ogólnymi prawami w świecie ciał, mając na celu dobro powszechne wszystkich stworzeń (nie tylko ludzi), dlatego nie zachowuje się kapryśnie, znosząc prawa przez cuda ${ }^{29}$. W jego ocenie byłoby niezgodne z Boską mądrością zawieszanie praw przyrody dla zrealizowania jakiegoś cudu. Byłoby śmieszne, gdyby Bóg przez cud zapobiegał np. stłuczeniu szklanego naczynia ulubionego przez danego władcę albo zawieszał ogólne prawa po to, by bezbożny nie mógł bogacić się kosztem pobożnego lub oddychać tym samym powietrzem czy spożywać te same potrawy. Bóg nie może chcieć ogólnych praw, nie chcąc zarazem wszystkich poszczególnych skutków, które stąd koniecznie wynikają. Można powiedzieć, że Bóg tylko dlatego chciał każdego poszczególnego zdarzenia, ponieważ było ono zawarte w ogólnym projekcie, który On wybrał ${ }^{30}$.

Bayle nie wykluczał jednak szczególnej Opatrzności (besondere Vorsorge) w obszarze państwa moralnego, czyli działania łaski, niedostępnej poznaniu naturalnemu człowieka, przejawiającej się w odwróceniu kierunku ludzkiej woli od miłości własnej do miłości Boga, co wskazuje na wątek Augustyński, silnie obecny także w pismach współczesnego Bayle’owi Malebranche'a $^{31}$. Uważał, że cudowne działania Boga powinny jasno i wyraźnie dać do zrozumienia, jaki jest Bóg prawdziwy. W przeciwnym wypadku można by powątpiewać w wydarzenia nazywane cudami, jeśli sprzeciwiałyby się one Boskiej świętości, dobroci, sprawiedliwości i mądrości.

Do przesądu na temat komet powracał Bayle wielokrotnie, koncentrując uwagę na wykazywaniu niedorzeczności, do których prowadzi ów przesąd. Jedną z nich jest pogląd, że pyłki komet fruwające w powietrzu miałyby

${ }^{28}$ Tamże, 200-201.

${ }^{29}$ Tamże, 407, 470.

30 Tamże, 474.

${ }^{31}$ Tamże, 313, 337, 342, 344, 366, 474. Bayle wyraźnie powoływał się na pracę Nicolasa Malebranche’a, Traité de la nature et de la grậce (Traktat o naturze i łasce) z roku 1680, Bayle, Verschiedene, 474. 
powodować przyszłe nieszczęścia, jak gdyby były wyposażone w rozum. Należałoby także uznać, że inaczej działają na ciała, podległe prawom mechaniki, a inaczej na dusze, dysponujące wolnością. Gdyby odwołać się do przykładu wojny trojańskiej, niedorzecznością byłoby uznanie tezy, że jedne cząsteczki komet spowodowały odwzajemnioną miłość Parysa do Heleny, inne zaś - gniew Menelaosa, jeszcze inne - wojenny zamiar Agamemnona, jeszcze inne - decyzję Priama o niewydaniu Heleny posłom greckim. Nawet gdyby nie było komet, te same namiętności pisałyby historię powszechną ${ }^{32}$.

Bayle uważał, że człowiek rozumny, który myślą przenosi się w odległą przeszłość oraz z różnych historii, dostarczających wiedzy o świecie, poznaje zasady, do których odnoszą się powszechne działania, potrafi bez pomocy kłamliwego astrologa snuć słuszne przypuszczenia (Mutmaßungen) na temat świata ludzkiego. Jako przykład podawał to, że Cyceron przewidział zmierzch Republiki Rzymskiej, co znalazło potwierdzenie w rzeczywistości. Wystarczyła mu znajomość charakteru Cezara oraz specyfiki wojny domowej, by postawić trafną hipotezę co do przyszłych losów własnej ojczyzny ${ }^{33}$.

W zakończeniu swego pisma polemicznego Bayle (unikając tym razem zbędnych dygresji) przedstawił podsumowanie wątku dotyczącego komet, przypominając, że nie mamy żadnych racji a priori ani racji a posteriori, które mogłyby potwierdzić tezę o kometach jako przyczynach sprawczych zjawisk szkodliwych w świecie ludzkim, takich jak wojny, pojawienie się nowych religii, głód, trzęsienia ziemi itp. Również nie mamy żadnych racji, by uznać, że komety są naturalnymi lub ustanowionymi przez Boga znakami przyszłych nieszczęśśc ${ }^{34}$.

Drugim obok komet ważnym wątkiem refleksji Baylea jest przesąd wyrażony w mniemaniu, że ateista zaprzeczający istnieniu Boga nie może być człowiekiem cnotliwym. Zakłada się niesłusznie, że „skoro człowiek nie ma żadnej religii, musi więc koniecznie oddać się wszelkim rodzajom występków lub wszelkim rodzajom przyjemności" ${ }^{35}$. Założenie to z kolei prowadziłoby do błędnego wniosku, że niemożliwe jest społeczeństwo ateistów ze względu na brak hamulca powściągającego ludzkie namiętności.

\footnotetext{
${ }^{32}$ Bayle, Verschiedene, 482.

${ }^{33}$ Tamże, 486.

34 Tamże, 535.

35 Tamże, 379.
} 
Jak argumentował Bayle, przyczyną błędu we wspomnianym wnioskowaniu jest fałszywe wyobrażenie, że człowiek działa zawsze według zasad religii, w którą wierzy. Praktyka poświadcza jednak zupełnie inny stan rzeczy, o czym traktują różnorodne świadectwa historyczne. Motorem działań są zawsze ludzkie namiętności, co można śledzić w zachowaniach pogan, chrześcijan, a także umysłów indyferentnych religijnie, nieopowiadających się za jakąkolwiek konfesją. Nawet ci, którzy uważali chrześcijaństwo za jedyną prawdziwą religię, musieli przyznać, że zewnętrzna służba Bogu (posty, msze, sakramenty, modlitwy) nie prowadzi do przemiany wewnętrznej człowieka, wyrażającej się w miłości cnoty i odrazie do występku $^{36}$. Toteż bardzo wielu chrześcijan żyje niezgodnie z prawami Boga zapisanymi w Ewangelii oraz realizuje najgorsze rodzaje występków moralnych. Nie przeszkadza im w tym ani wzgląd na Boskie doskonałości, ani nawet strach przed karą wieczną lub nadzieja na zbawienie. Bayle zdawał sobie sprawę, że chrześcijaństwo po reformacji przestało być monolitem, ponieważ podzieliło się na wiele konfesji, różniących się co do dogmatów, rodzajów kultu religijnego itd. We Francji (ojczyźnie Bayle’a) dokonywały się niesłychane okrucieństwa, których źródłem była źle rozumiana gorliwość religijna katolików, chcących wymusić na hugenotach nawrócenie na katolicyzm, stosując metodę przekupstwa lub prześladowania (konfiskata mienia, tortury, a nawet wyroki śmierci) ${ }^{37}$. Było to postępowanie sprzeczne z zasadami samej religii, a także zdrowego rozumu.

Bayle sam doświadczył tego rodzaju prześladowań, gdy po krótkim epizodzie opowiedzenia się za religią katolicką powrócił jednak do wiary własnych przodków, którzy byli hugenotami. Pod wpływem owych gorzkich doświadczeń zauważał, że „duch religii katolickiej bardziej występuje przeciw teoriom, które są niezgodne z ich dogmatami kościelnymi, niż przeciw nieuporządkowanemu życiu” ${ }^{38}$. Krytycznie oceniał również to, że niektó-

36 Tamże, 278-279. Bayle odróżnia zatem prawdziwą religię, która ma moc doskonalenia moralnego człowieka, od pseudoreligii, czyli wszelkich zewnętrznych form służby Bogu, współistniejących z głębokim zepsuciem moralnym ludzi, którzy należą do danej konfesji i prześladują wszelkich innowierców. Z tego powodu opowiadał się za pełną tolerancją.

37 Tamże, 190-192, 419.

${ }^{38}$ Tamże, 422. 
rzy chrześcijanie, powołując się na objawienia indywidualne (niemożliwe do zweryfikowania przez inne jednostki), nawoływali do nierozumnych działań, np. Bernard z Clairvaux zachęcał do udziału w wyprawach krzyżowych, które trudno uznać za przynoszące chwałę Bogu ${ }^{39}$. Bayle uważał, że proroctwa czy objawienia indywidualne bardzo często są fałszywe, nieuznawane przez Kościół instytucjonalny, a nawet jeśli byłyby prawdziwe, nie jesteśmy zobowiązani wierzyć w nie ślepo, jeśli nie mamy niezbitych dowodów (unumstößliche Beweise). Nie ulega wątpliwości natomiast, że jesteśmy - jego zdaniem - zobowiązani we wszystkich czasach postępować zgodnie z rozsądkiem i zdrowym rozumem, które Bóg dał człowiekowi (obok swojego Boskiego Słowa) po to, by były regułą naszego zachowania ${ }^{40}$.

W tym miejscu warto zauważyć, że jeśli Boskie Słowo zacieśnia grupę ludzi do tych, którzy znają Objawienie zawarte w Biblii, to zdrowy rozum jest czymś powszechnym w całym świecie ludzkim, bez względu na różnice konfesyjne. $Z$ tego względu Bayle pisał, że Bóg zachowuje w ateistach rozum, dzięki któremu wszyscy ludzie poznają prawdę pierwszych zasad poznania i działania moralnego ${ }^{41}$. Nawet bez pomocy Objawienia światło rozumu może doprowadzić do wniosku, że są rzeczy zgodne z rozumem, a nie tylko przyjemne czy korzystne dla nas. Zdaniem Bayle’a pojęcie sprawiedliwości (Billigkeit) jest stare jak świat, starsze niż Księga Mojżesza. Wynikałby stąd wniosek, że możliwe jest jednak społeczeństwo ateistów, w którym byłyby przestrzegane zasady moralne (nieodwołujące się do założeń religijnych). Można je pomyśleć bez sprzeczności jako podobne do społeczeństwa pogan w odniesieniu do sfery moralnej i działań obywatelskich, porządkowanych przez świeckie prawa stanowione, abstrahując od tego, co teologowie chrześcijańscy zwą łaską uświęcającą Boga ${ }^{42}$. Bayle wielokrotnie zalecał powściągliwość w ocenie ateistów, których intencje nie są dostępne ograniczonemu ludzkiemu poznaniu, tylko - co najwyżej - skutki empiryczne określonych działań ${ }^{43}$.

\footnotetext{
39 Tamże, 298.

${ }^{40}$ Tamże, 519.

${ }^{41}$ Tamże, 382-383.

42 Tamże, 368.

${ }^{43}$ Tamże, 342.
} 
Zdaniem Bayle’a należy unikać pochopnych sądów także z tego względu, że nie dysponujemy kronikami jakiegokolwiek ludu ateistów. Nie mamy żadnej pewnej informacji o obyczajach, prawach i zwyczajach takich ludów, które jak się mówi, nie znają żadnej religii ${ }^{44}$. Natomiast dysponujemy obszernym registrem najbardziej odrażających występków realizowanych przez wyznawców różnych religii politeistycznych i monoteistycznych, w tym chrześcijan, z czego płynie wniosek, że wyznawana religia nie ma mocy poskromienia zła w naturze ludzkiej. Dlatego w każdej społeczności potrzebne są prawa stanowione, które zapewniają jej trwałość.

Doświadczenie potwierdza, że istnieje ogromna różnorodność w zakresie przedmiotów wiedzy (mniemań), a także przedmiotów pożądania w świecie ludzkim, jeśli prześledzić pisemne świadectwa pochodzące $\mathrm{z}$ różnych epok historycznych i różnych obszarów geograficznych. Warto odnotować ostrożność badawczą Bayle’a, który dobrze wiedział, że „ludzki rozum jest zdolny do wszystkich cudownych rzeczy, które tylko można wymyśleć, dlatego nie możemy nigdy ustanowić dla niego reguły, która nie miałaby tysiąca wyjątków. Stąd należy opierać się na tym, co zdarza się najczęściej: mianowicie że nie ogólne mniemania rozumu, lecz aktualne namiętności serca determinują nas do podejmowania pewnych działań" ${ }^{45}$. Wprawdzie jak pisał Bayle - nie dysponujemy informacjami o ludach Południa, Afryki i Ameryki, co skłania nas do wnioskowania o wszystkich ludziach na podstawie znanego nam świata ${ }^{46}$, jednak możemy przyjmować $\mathrm{z}$ dużym prawdopodobieństwem, że nieprawdziwe jest założenie, iż poznanie poprzedza (bądź determinuje) miłość do przedmiotu. Można bowiem znać zasady, a mimo to postępować wbrew nim. Można wiedzieć np., że istnieje Bóg, a jednak nie miłować go jako dobro najwyższe (summum bonum), tylko kierować się miłością własną, która jest korzeniem pychy, chciwości, okrucieństwa, nieczystości, zawiści itd.

Bayle zauważał, że metafizycy, którzy twierdzą, że człowiek jest rozumnym zwierzęciem lub rozumnym stworzeniem, nie znają go z opowiadań

\footnotetext{
${ }^{44}$ Tamże, 274.

45 Tamże, 295.

46 Tamże, 91.
} 
o jego działaniach ${ }^{47}$. Rozpatrują oni raczej abstrakcyjne pojęcie człowieka, a nie człowieka konkretnego, który działa zawsze w określonych okolicznościach hic et nunc pod wpływem temperamentu, dominującej namiętności, siły przyjętych nawyków, smaku lub wrażliwości na pewne przedmioty ${ }^{48}$. Według Bayle’a „racji tego, że człowiek decyduje się na pewne działanie bardziej niż na inne, nie należy szukać w ogólnym poznaniu o rzeczach, które powinien czynić, lecz w szczególnym sądzie, który wydaje on o każdej rzeczy (Sache) [...] Ów szczególny sąd może wprawdzie zgadzać się z ogólnymi pojęciami tego, co powinno się czynić, jednak najczęściej tak się nie dzieje"49. Sama introspekcja jest niewystarczającym narzędziem poznania, dlatego potrzebne są świadectwa innych ludzi, poszerzające naszą wiedzę o naturze ludzkiej. W ocenie wiarygodności owych świadectw warto pamiętać o tym, że jeśli historyk potrafi dostrzegać pozytywne strony nawet u swoich przeciwników, z którymi jest w sporze, dowodzi tym samym rzetelności własnego postępowania. Jeśli np. ojcowie Kościoła, pisząc przeciwko poganom, wskazywali wśród nich na godne szacunku wyjątki, można uznać ich postawę za bardziej wiarygodną, niż gdyby gromadzili wyłącznie informacje o błędach i występkach w świecie przedchrześcijańskim.

Jeśli prześledzić biografie jednostek ludzkich, nazywanych ateistami (np. Epikur i Spinoza), można stwierdzić, że wielu z nich prezentowało wysoki poziom moralny, zawstydzając niejednokrotnie swoich prześladowców, którzy przydawali im różne niesprawiedliwe etykietki ${ }^{50}$. Hipoteza ta

47 Tamże, 263, 290. „[...] człowiek jest pewnym stworzeniem, które przy całym swym rozumie jednak nie działa tak, jak wie, że powinien działać”. Zob. tamże, 377, 378, 379, 381.

48 Tamże, 287.

49 Tamże, 288.

${ }^{50}$ Zarówno Seneka, jak i św. Hieronim pisali korzystnie o przyzwoitym życiu Epikura, chociaż żaden z nich nie był zwolennikiem epikureizmu, co wzmacnia ich wiarygodność, zob. Bayle, Verschiedene, 371-372, 382. Również Spinoza mimo osobliwych zasad własnej filozofii był człowiekiem prawym, zob. tamże, 390. Podobną dążność do rehabilitacji umysłów, zwanych kacerzami lub ateistami, można zauważyć w pracy: Gottfried Arnold, Unparteiische Kirchenund Ketzerhistorie 1699/1700, t. 2, (Schaffhausen: Emanuel und Benedict Hurter, 1741), zwł. rozdz. XVI: Von denen Atheisten, wie auch denen so genannten Naturalisten, Deisten und Latitudinaristen in diesem seculo, 207-222. Bayle był prekursorem oświecenia francuskiego, natomiast Arnold - oświecenia niemieckiego. Zob. Honorata Jakuszko, „Oświeceniowa filozofia”, w: Powszechna encyklopedia filozofi, t. 7, red. Andrzej Maryniarczyk (Lublin: Polskie Towarzystwo Tomasza z Akwinu, 2006), 906-915. 
nie tylko jest niesprzeczna z zasadami rozumu, ale ponadto znajduje potwierdzenie w doświadczeniu. Wynika stąd wniosek, że ateista może być człowiekiem przyzwoitym oraz że może istnieć społeczeństwo ateistów.

Wskazane w artykule dwa wątki (o kometach i o ateistach) jako przykłady władzy przesądów nad zdrowym rozumem i nad prawdziwą religią jednocześnie ujawniają specyficzny (niesystemowy) styl myślenia i pisania Bayle’a, który reguły kartezjanizmu przeniósł z obszaru przyrodoznawstwa do obszaru historii i teologii ${ }^{51}$. Temperament Bayle’a lepiej wyrażał się w stawianiu zarzutów, w podważaniu różnych wariantów dogmatyzmu, w zestawianiu przeciwstawnych poglądów niż w ostatecznym rozstrzyganiu, który z nich jest bardziej prawdopodobny i zgodny ze zdrowym rozumem.

W dążeniu do bezstronności i wiarygodności niewątpliwie wyprzedzał wiele umysłów swej epoki, niezdolnych zrozumieć jego właściwych intencji bądź zniewolonych przez uprzedzenia i przesądy. Wiedział, że powierzchowny umysł mógłby mu imputować to, że nie postępuje bezstronnie, ponieważ bierze w obronę ateistów, jednak miał nadzieję, że umysł przenikliwy zauważy dążność przeciwną, widoczną chociażby w próbie wykazywania na podstawie świadectw historycznych, że większość chrześcijan żyje bezbożnie, mimo iż uznaje prawdy ewangeliczne, dlatego ich odpowiedzialność jest większa niż tych, którzy nie znają owych prawd ${ }^{52}$.

Nie ma powodu, by wątpić w szczerość wyznania Bayle’a, który pisał do uczonego doktora Sorbony o możliwości pojednania wglądu filozofii ze

${ }^{51}$ Friedrich Jodl, Geschichte der neueren Philosophie. Aus dem Nachlaß herausgegeben von Karl Roretz (Wien: Rikola Verlag, 1924), 232.

${ }^{52}$ Bayle, Verschiedene, 341. Tego rodzaju zarzuty stawiane były także pod adresem Dictionnaire historique et critique. Bayle odpowiadał na nie, zob. Pierre Bayle, Wyjaśnienie pierwsze, w: Słownik historyczny i krytyczny. Wybór, przeł. Kinga Kaśkiewicz, Adam Grzeliński i in. (Toruń: Wydawnictwo Naukowe Uniwersytetu Mikołaja Kopernika, 2014), 216-226. Ze względu na cel artykułu, którym jest rekonstrukcja poglądów Bayle’a na temat kondycji ludzkiej, nie wchodzę w polemikę z różnymi - historycznie zmiennymi - znaczeniami terminu „ateizm”. Zainteresowanych odsyłam do publikacji takich jak: Hans-Walter Schütte, „Atheismus”, w: Historisches Wörterbuch der Philosophie, red. Joachim Ritter, Karlfried Gründer, Gottfried Gabriel, t. 1 (Basel: Schwabe \&Co Verlag, 1971), 595-599. Zofia Zdybicka, „Ateizm”, w: Powszechna encyklopedia filozofii, red. Andrzej Maryniarczyk, t. 1 (Lublin: Polskie Towarzystwo Tomasza z Akwinu, 2000), 371-390. 
światłem sumienia ${ }^{53}$ pod warunkiem wszakże zdystansowania się od przesądów, zakorzenionych stosunkowo trwale w ludzkich umysłach od wielu stuleci. Pomocą w tym zakresie mogą być reguły metodologiczne wielokrotnie przywoływane w piśmie polemicznym na temat komet.

\section{Bibliografia}

Arnold Gottfried. 1741. Unparteiische Kirchen- und Ketzerhistorie 1699/1700. T. 2. Schaffhausen: Emanuel und Benedict Hurter.

Bayle Pierre. 2014. Stownik historyczny i krytyczny. Wybór. Przeł. Kinga Kaśkiewicz, Adam Grzeliński i in. Toruń: Wydawnictwo Naukowe Uniwersytetu Mikołaja Kopernika.

Bayle Pierre. 1975. Verschiedene einem Doktor der Sorbonne mitgeteilte Gedanken über den Kometen, der im Monat Dezember 1680 erschienen ist, przeł. Johann Christoph Gottsched. Leipzig: Verlag Philipp Reclam.

Cassirer Ernst. 1973. Die Philosophie der Aufklärung. Tübingen: J. C. B. Mohr (Paul Siebeck).

Copleston Frederick. 1996. Historia filozofii. T. 6: Od Wolffa do Kanta, przeł. Jerzy Łoziński. Warszawa: PAX.

Dąmbska Izydora. 1958. Sceptycyzm francuski XVI i XVII wieku. Łódź: Państwowe Wydawnictwo Naukowe.

Friedrich der Grosse. 1941. Briefe über die Religion. Berlin: Nordland Verlag.

Geißler Rolf. 1975. „Einleitung”. W: Pierre Bayle, Verschiedene einem Doktor der Sorbonne mitgeteilte Gedanken über den Kometen, der im Monat Dezember 1680 erschienen ist. Przeł. Johann Christoph Gottsched. 5-28. Leipzig: Verlag Philipp Reclam.

Grzeliński Adam. 2014. „Wprowadzenie”. W: Pierre Bayle, Słownik historyczny i krytyczny. Wybór, przeł. Kinga Kaśkiewicz, Adam Grzeliński i in. 9-31. Toruń: Wydawnictwo Naukowe Uniwersytetu Mikołaja Kopernika.

Hirsch Emanuel. 1949. Geschichte der neuern evangelischen Theologie. T. 1, Gütersloh: Bertelsmann Verlag.

Jakuszko Honorata. 2006. „Oświeceniowa filozofia”. W: Powszechna encyklopedia filozofii. Red. Andrzej Maryniarczyk. T. 7, 906-915. Lublin: Polskie Towarzystwo Tomasza z Akwinu.

${ }^{53}$ Zob. przyp. 2. 
Jodl Friedrich. 1924. Geschichte der neueren Philosophie. Aus dem Nachlaß herausgegeben von Karl Roretz. 230-237. Wien: Ricola Verlag.

Popkin Richard Henry. 2003. The History of Scepticism from Savonarola to Bayle. Oxford: Oxford University Press.

Schneiders Werner. 1983. Aufklärung und Vorurteilskritik. Studien zur Geschichte der Vorurteilstheorie. Stuttgart: Frommann-Holzboog.

Schütte Hans-Walter. 1971. „Atheismus”. W: Historisches Wörterbuch der Philosophie. Red. Joachim Ritter, Karlfried Gründer, Gottfried Gabriel. T. 1, 595-599. Basel: Schwabe\&Co Verlag.

Vorländer Karl. 1908. Geschichte der Philosophie. T. 2: Philosophie der Neuzeit. 124-128. Leipzig: Verlag der Dürr'schen Buchhandlung.

Zawojska Teresa. 2000. „Bayle Pierre”. W: Powszechna encyklopedia filozofii. Red. Andrzej Maryniarczyk. T. 1, 509-512. Lublin: Polskie Towarzystwo Tomasza z Akwinu.

Zdybicka Zofia. 2000. „Ateizm”. W: Powszechna encyklopedia filozofii. Red. Andrzej Maryniarczyk. T. 1, 371-390. Lublin: Polskie Towarzystwo Tomasza z Akwinu. Ziemińska Renata. 2013. Historia sceptycyzmu. W poszukiwaniu spójności, 233-241. Toruń: Wydawnictwo Naukowe Uniwersytetu Mikołaja Kopernika.

\section{Abstact \\ The Human Condition According to Pierre Bayle}

Pierre Bayle, the author of a publication titled Pensées diverses sur la comète (1682), translated by J. Ch. Gottsched as Verschiedene Gedanken über einen Kometen (1741) had developed a set of methodological principles, helpful in the eradication of superstition from human knowledge. He paid particular attention to the elimination of a certain superstition that comets are the causes or heralds of future calamities, demonstrating the incongruity of the aforementioned thesis with the laws of common sense as well as experience (historical testimonies). He also criticized the superstition that an atheist cannot be a moral person, and that atheists cannot form a society. He showed that the underlying force of human actions is not the knowledge of religious principles, but of passions, especially self-love.

Key words: Pierre Bayle; experience; reason; superstition; religion; atheism; morality.

przekład Dominika Boroń 


\section{Streszczenie}

\section{Kondycja ludzka według Pierre’a Bayle’a}

Pierre Bayle, autor publikacji Pensées diverses sur la comète (1682) przetłumaczonej przez J. Ch. Gottscheda jako Verschiedene Gedanken über einen Kometen (1741), opracował reguły metodologiczne pomocne w zwalczaniu przesądów w ludzkiej wiedzy. Szczególną uwagę poświęcił eliminacji przesądu, że komety są przyczynami lub oznakami przyszłych nieszczęść, wykazując niezgodność tej tezy zarówno z zasadami zdrowego rozumu, jak i z doświadczeniem (świadectwami historycznymi). Krytykował także przesąd, że ateista nie może być człowiekiem moralnym oraz że nie może istnieć społeczeństwo ateistów. Wykazywał, że siłą motoryczną ludzkich działań nie jest wiedza o zasadach religii, lecz namiętności, a zwłaszcza miłość własna.

Słowa kluczowe: Pierre Bayle; doświadczenie; rozum; przesąd; religia; ateizm; moralność. 